\title{
Molecular Characterization of Heat-Induced HSP11.0 and Master-Regulator HSF from Cotesia chilonis and Their Consistent Response to Heat Stress
}

\author{
Fu-Jing He ${ }^{1}$, Feng Zhu ${ }^{2}$, Ming-Xing Lu ${ }^{1,3, *}$ and Yu-Zhou Du ${ }^{1,3, *(D)}$ \\ 1 College of Horticulture and Plant Protection \& Institute of Applied Entomology, Yangzhou University, \\ Yangzhou 225009, China; hefujing2020@163.com \\ 2 Plant Protection and Quarantine Station of Jiangsu Province, Nanjing 210000, China; \\ changyawen1992@163.com \\ 3 Joint International Research Laboratory of Agriculture and Agri-Product Safety, Yangzhou University, \\ Yangzhou 225009, China \\ * Correspondence: lumx@yzu.edu.cn (M.-X.L.); yzdu@yzu.edu.cn (Y.-Z.D.)
}

Citation: He, F.-J.; Zhu, F.; Lu, M.-X.; Du, Y.-Z. Molecular Characterization of Heat-Induced HSP11.0 and Master-Regulator HSF from Cotesia chilonis and Their Consistent Response to Heat Stress. Insects 2021, 12, 322. https://doi.org/10.3390/ insects12040322

Academic Editor: Volker L. Loeschcke

Received: 24 February 2021

Accepted: 31 March 2021

Published: 4 April 2021

Publisher's Note: MDPI stays neutral with regard to jurisdictional claims in published maps and institutional affiliations.

Copyright: (c) 2021 by the authors. Licensee MDPI, Basel, Switzerland. This article is an open access article distributed under the terms and conditions of the Creative Commons Attribution (CC BY) license (https:/ / creativecommons.org/licenses/by/ $4.0 /)$.
Simple Summary: Small heat shock proteins (sHSPs) are members of the heat shock protein (HSP) family that play an important role in heat stress, and heat shock factors (HSFs) are transcriptional activators that mainly regulate the expression of HSPs. Cotesia chilonis, the major endoparasitoid of Chilo suppressalis, widely distributes in China and other Asian regions. Previous studies have shown that $C$. chilonis has a certain thermal tolerance. Here, heat-induced HSP11.0 and master-regulator HSF were cloned and characterized from $C$. chilonis. The transcription patterns of them in response to different temperatures and time course after temperature treatment were analyzed. This study is the first report on the analysis on $h s f$ gene of $C$. chilonis. The results of expression patterns will provide new insights into thermoregulation of $C$. chilonis in response to climate change.

Abstract: Small heat shock proteins (sHSPs) are members of the heat shock protein (HSP) family that play an important role in temperature stress, and heat shock factors (HSFs) are transcriptional activators that regulate HSP expression. Cotesia chilonis, the major endoparasitoid of Chilo suppressalis, modulates the C. suppressalis population in the field. In this study, we cloned and characterized two genes from C. chilonis: the heat-induced HSP11.0 gene (Cchsp11.0) that consisted of a 306-bp ORF, and the master regulator HSF (Cchsf) containing an 1875-bp ORF. CcHSP11.0 contained a chaperonin cpn10 signature motif that is conserved in other hymenopteran insects. CcHSF is a typical HSF and contains a DNA-binding domain, two hydrophobic heptad repeat domains, and a C-terminal trans-activation domain. Neither Cchsp11.0 or Cchsf contain introns. Real-time quantitative PCR revealed that Cchsp11.0 and Cchsf were highly induced at $36{ }^{\circ} \mathrm{C}$ and $6{ }^{\circ} \mathrm{C}$ after a 2 -h exposure. Overall, the induction of Cchsf was lower than Cchsp11.0 at low temperatures, whereas the opposite was true at high temperatures. In conclusion, both Cchsp11.0 and Cchsf are sensitive to high and low temperature stress, and the expression pattern of the two genes were positively correlated during temperature stress.

Keywords: small heat shock proteins; heat shock factors; Cotesia chilonis; temperature stress; gene expression

\section{Introduction}

Chilo suppressalis (Walker) is a detrimental rice pest that widely distributed in rice fields of China, which is known as the striped rice stem borer [1]. Cotesia chilonis (Munakata) is the major endoparasitoid of Chilo suppressalis (Walker), and has become the dominant parasitic wasp of C. suppressalis as global temperatures have risen [2-4].

Global warming has garnered widespread attention on the influence of temperature [5]. As an important environmental factor, temperature influences the growth and 
development of insects and the structure and function of cellular proteins [6-8]. Insects adopt various survival strategies when exposed to temperature stress; this heat shock response (HSR) is rapidly induced by heat or other environmental and physiological stressors [9]. The HSR can remove misfolded or damaged proteins in the cytoplasm and nucleus and also contributes to the expression of genes encoding heat shock proteins (HSPs). The HSPs are highly-conserved proteins that are induced by suboptimal temperatures; they function to prevent protein denaturation and help restore conformation and biological activity [2]. The main function of HSPs is to improve the tolerance of organisms to various environmental stresses, such as temperature, hunger, heavy metals, ultraviolet rays and pesticides; furthermore, and they can be used as biomarkers for various stresses [10,11]. On the basis of molecular weight and amino acid similarity, the HSP superfamily can be divided into HSP100, HSP90, HSP70, HSP60, HSP40 and small heat shock proteins (sHSPs) [12,13]. sHSPs are relatively small (about $12-43 \mathrm{kDa}$ ), and possess diverse amino acid sequences; however, they share a conserved $\alpha$-crystallin domain (ACD) [14].

Heat shock transcription factors (HSFs) are crucial regulatory factors of the HSR that are conserved in eukaryotes $[15,16]$. HSFs utilize a conserved regulatory mechanism where heat shock transcription factor 1 (HSF1) is the major transcription factor to regulator; this factor is expressed in most tissues and cells in response to heat stress [17]. HSF1 is comprised of four conserved domains including a DNA-binding domain (DBD), hydrophobic heptad repeat domains-heptad repeat ofhydrophobic amino acids A and B (HR-A/B) and C-terminal heptad repeat (HR-C) and a C-terminal trans-activation domain (CTAD) [18]. The structure and function of HSF1 has been well-studied in mammals and Drosophila melanogaster (Meigen) [19,20].

sHSPs are a common feature of insects, and numerous studies have reported the response of insect sHSPs to temperature [21-24]. For example, Sihsp19.6, Sihsp20.6 and Sihsp21.4 in Sesamia inferens and Lshsp19.5, Lshsp20.8, and Lshsp21.7 in Liriomyza sativa were up-regulated when exposed to low temperature stress [25,26]. In Chilo suppressalis, Cshsp23.9 was induced at high temperature $\left(36^{\circ} \mathrm{C}\right)$ but did not respond to low temperature stress [27]. In Plutella xylostella, 12 Pxhsps were significantly induced by high and low temperatures [28]. In addition, a few reports exist documenting HSF1 in other insect species including Bactrocera dorsalis (Hendel), Helicoverpa armigera (Hübner), Bombyx mori (Linnaeus) and Mamestra brassicae (Linnaeus) [18,29,30]; however, studies showing a relationship between the expression of $h s f s$ and shsps under temperature stress in insects are lacking.

Many studies demonstrated that various sHSPs play a significant part in thermotolerance of insects $[1,2,27]$. Our previous studies have shown that $C c$ HSPs play an important role in temperature tolerance; however, with the exception of Cchsp 40 , there is no evidence for the role of sHSPs in thermotolerance of C. chilonis [2,27]. However, Moreover, the regulatory mechanism between HSFs and sHSPs on protection is worthy of further study, which can start by studying the expression link between $h s f s$ and shsps in response to temperature stress. In this study, a second gene encoding a sHSP, Cchsp11.0, and an HSF factor, Cchsf, were cloned and characterized in response to thermal stress. The results provide new insights into thermoregulation of $C$. chilonis in response to climate change.

\section{Materials and Methods}

\subsection{Experimental Insects}

C. suppressalis and C. chilonis were collected from a suburb of Yangzhou $\left(32.39^{\circ} \mathrm{N}\right.$, $119.42^{\circ} \mathrm{E}$ ) and reared under the laboratory conditions at $27 \pm 1{ }^{\circ} \mathrm{C}, 60-70 \% \mathrm{RH}$ and a $16: 8 \mathrm{~h}$ (light/dark) photoperiod [2]. C. suppressalis larvae were reared on an artificial diet [1]. C. chilonis adults were supplied with a $10 \%$ honey/water solution and propagated using 5 th instar larvae of $C$. suppressalis as hosts. 


\subsection{Sample Treatments}

\subsubsection{Different Temperature Treatments}

For different temperature treatments, one-day-old adults of $C$. chilonis were subjected to $-13,-12,-9,-6,-3,0,27,30,33$, or $36^{\circ} \mathrm{C}$ for $1 \mathrm{~h}$ in a constant-temperature incubator [2]; samples were then placed in a climate-controlled incubator and allowed to recover at $27^{\circ} \mathrm{C}$ for $1 \mathrm{~h}$. Each treatment contained 30 one-day old adults, and all treatments were replicated three times.

\subsubsection{Thermal Treatment at Different Times}

For thermal treatment at different times, one-day-old adults of $C$. chilonis were subjected to $36^{\circ} \mathrm{C}$ or $-6^{\circ} \mathrm{C}$ for $15 \mathrm{~min}, 30 \mathrm{~min}, 1 \mathrm{~h}, 2 \mathrm{~h}, 4 \mathrm{~h}$, or $8 \mathrm{~h}$ in a controlled temperature incubator; samples were then transferred to a climate-controlled incubator to recover at $27^{\circ} \mathrm{C}$ for $1 \mathrm{~h}$. Controls were maintained at $27^{\circ} \mathrm{C}$ for $1 \mathrm{~h}$. Temperature selection for the treatments were based on previous articles [2]. Each treatment contained 40 one-day old adults, and all treatments were replicated four times.

\subsection{Total RNA Isolation and Synthesis of First Strand cDNA}

Total RNA was extracted from C. chilonis using the SV Total RNA Isolation System (Promega, Madison, WI, USA). RNA purity and concentration were measured by agarose gel electrophoresis and spectrophotometry (NanoDrop One, Thermo Fisher Scientific, Madison, WI, USA). The first strand of cDNA was synthesized using RevertAid First Strand cDNA Synthesis Kit (Thermo, Madison, WI, USA) and cDNAs for $5^{\prime}$ - and $3^{\prime}$-RACE were synthesized by SMARTerTM cDNA Amplification Kit (Clontech, Mountain View, CA, USA).

\subsection{Cloning and Genome Amplification}

Partial gene sequences were obtained from the $C$. chilonis transcriptome (unpublished data), and according to the primer design principle and nucleotide sequence we obtained, specific primers were designed by Primer Premier 5 to verify fragments using the first strand of cDNA as template (Table 1). Full-length cDNA sequences of genes were obtained with $5^{\prime}$ - and 3'-RACE (SMARTerTM RACE, Clontech, Mountain View, CA, USA), and gene-specific primers were designed for verifying full-length cDNA sequences using the 5'-RACE template (Table 1). Genomic DNA of $C$. chilonis adults was extracted using the AxyprepTM Multisource Genomic DNA Kit (Axygen, New York, NY, USA), and primers (Table 1) were designed to amplify genomic fragments of Cchsp11.0 and Cchsf for subsequent cloning or sequencing.

Table 1. Primers used in this study.

\begin{tabular}{cccc}
\hline Primer Name & Primer Sequences $\left(5^{\prime}-\mathbf{3}^{\prime}\right)$ & Tm $\left({ }^{\circ} \mathbf{C}\right)$ & $\varepsilon^{\mathbf{b}}(\mathbf{\%})$ \\
\hline Fragment verification & & \\
\hline$h s p 11.0-F$ & CGGGAACAAATCAACAT & 46.3 \\
$h s p 11.0-R$ & ACTCGGTCCATCAAAGG & 51.3 \\
$h s f-F$ & AGAACGCAACAACCAAG & 50.0 \\
$h s f-R$ & CAACTACAGAACCATCAGAG & 45.0 \\
$h s p 11.0-5^{\prime}$ & Rapid-amplification of cDNA ends (RACE) & \\
$h s p 11.0-3^{\prime}$ & GAGCCAGGTCCAACAGCAACTACAG & 62.4 \\
$h s f-F$ & CGTTCAAAGAGCCGATGCTATAA & 54.8 \\
$h s f-R$ & CTTGCTGCTGGAGCCTGGATCAC & 63.5 \\
& ATTCCAGACATCCTACTCACCTC & 55.7 \\
$h s p 11.0-F$ & Verification of full-length cDNA & 51.1 \\
$h s p 11.0-R$ & AGTTATTCACCAGCAACGT & 42.4 \\
$h s f-F$ & GTTTGATAATTTCATAGAGC & 52.5 \\
\hline
\end{tabular}


Table 1. Cont.

\begin{tabular}{|c|c|c|c|c|}
\hline Primer Name & Primer Sequences $\left(5^{\prime}-3^{\prime}\right)$ & $\operatorname{Tm}\left({ }^{\circ} \mathrm{C}\right)$ & $\varepsilon^{b}(\%)$ & $\mathbf{R}^{2 \mathrm{c}}$ \\
\hline \multicolumn{5}{|c|}{ Verification of genome } \\
\hline$h s p 11.0-F$ & CTCAGATCTTATTCTTTCAT & 42.6 & & \\
\hline$h \operatorname{sp} 11.0-R$ & GTTTGATAATTTCATAGAGC & 42.4 & & \\
\hline$h s f-F$ & ATCACTAATACGACTCACTATAGGG & 52.5 & & \\
\hline$h s f-R$ & GAGCTGAATAAATACACTCACCA & 51.8 & & \\
\hline \multicolumn{5}{|c|}{ Real-time quantitative PCR ${ }^{a}$} \\
\hline hsp11.0-F & ACAAAGTTCTCСТCCСCG & & & \\
\hline$h s p 11.0-R$ & GCAACAATGTCTGATTCACG & 59.4 & 90.0 & 0.988 \\
\hline$h s f-F$ & TTAGGTGCTGAAAGTGCCGA & & & \\
\hline$h s f-R$ & AGTACGCAAGTCGAGCTGAA & 60.0 & 117.3 & 0.904 \\
\hline \multicolumn{5}{|c|}{ Reference gene in qRT-PCR ${ }^{a}$} \\
\hline$H 3-F$ & CGTCGCTCTTCGTGAAATCA & & & \\
\hline$H 3-R$ & TCTGGAAACGCAAGTCGGTC & 58.1 & 97.4 & 0.978 \\
\hline GAPDH-F & GAAGGTGGTGCCAAGAAAG & & & \\
\hline GAPDH-R & GCATGGACAGTGGTCATAAGA & 54.0 & 106.7 & 0.978 \\
\hline
\end{tabular}

Note: ${ }^{a}$ The qPCR primers used in this study were validated [31]. ${ }^{b}$ Real-time qPCR efficiency (calculated from the standard curve).

${ }^{c}$ Coefficient of determination.

\subsection{Sequence Analysis of Genes}

ORFs were identified with ORF Finder (https:/ / www.ncbi.nlm.nih.gov / orffinder/) (accessed on 12 December 2020), and deduced amino acid sequences were aligned with Clustal X [32]. Sequence analysis tools on the ExPASy Molecular Biology Server including Translate, Compute pI/MW, and Blast (Swiss Institute of Bioinformatics, Lausanne, Switzerland), were used to analyze the predicted sequences. Motif Scan (https: / / prosite.expasy. org/) (accessed on 12 December 2020) and InterPro (http://www.ebi.ac.uk/interpro/) (accessed on 12 December 2020) were used to identify motifs characteristic of the sHSPs family. Amino acid sequences of 18 sHSPs and 23 HSFs were downloaded from NCBI (https:/ / www.ncbi.nlm.nih.gov/) (accessed on 12 December 2020). Then phylogenetic trees were constructed by the neighbor-joining minimum evolution, maximum likelihood and maximum parsimony methods with 1000 bootstrap replicates using MEGA X [33].

\subsection{Real-Time qPCR Analysis}

Total RNA of different treatments was isolated as described above. The Bio-Rad iScriptTM cDNA Synthesis Kit (Bio-Rad, Laboratories, Berkeley, CA, USA) was used to reverse-transcribe $0.5 \mu \mathrm{g}$ total RNA into first strand cDNA. The primers used for real-time quantitative PCR (Table 1) were designed according to the full-length cDNA sequence of genes. Real-time PCR reactions were conducted by using SYBR Green I in a $20 \mu \mathrm{L}$ reaction volume containing $10 \mu \mathrm{L}$ iTaqTM SYBR ${ }^{\circledR}$ Green Supermix (Thermo, Madison, WI, USA), $6 \mu \mathrm{L} \mathrm{ddH} \mathrm{H}_{2} 0,2 \mu \mathrm{L} \mathrm{cDNA}$ template and $1 \mu \mathrm{L} 10 \mu \mathrm{M}$ each of the corresponding forward and reverse primers. PCR conditions were as follows: $3 \mathrm{~min}$ initial denaturation step at $95{ }^{\circ} \mathrm{C}$, followed by 40 cycles of $15 \mathrm{~s}$ denaturation at $95^{\circ} \mathrm{C}$, and $30 \mathrm{~s}$ annealing at the Tm for each gene (Table 1). Melting curve analysis was carried out to evaluate the homogeneity of amplified PCR products, and each PCR reaction was replicated in triplicate.

\subsection{Statistical Analysis}

Relative quantitative analysis was performed by the $2^{-\Delta \Delta \mathrm{Ct}}$ method to obtain the relative expression level of each treatment. $H 3$ encoding histone 3 was regarded as a low-temperature reference gene, and GAPDH encoding glyceraldehyde-3-phosphate dehydrogenase was regarded as the high-temperature reference gene [31]. Differences in mean values were analyzed using one-way ANOVA. Homogeneity of variances among treatments was measured by Levene's test, and significance differences were assessed by Tukey's test. All statistics were performed using SPSS16.0 software and represented as means \pm SE (standard error). 


\section{Results}

\subsection{Characteristics of Sequenced Genes}

The full-length cDNA sequence of Cchsp11.0 was 508 bp (GenBank accession no. MN176104) (https:/ / www.ncbi.nlm.nih.gov/ accessed on 10 October 2020) and contained a 132-bp $5^{\prime}$ untranslated region (UTR), a 306-bp open reading frame (ORF), and 70-bp $3^{\prime}$ UTR (Figure S1). The predicted CcHSP11.0 protein contained 101 amino acids with a molecular mass of $11.0 \mathrm{kDa}$ and theoretical isoelectric point $(p I)$ of 8.03. MotifScan indicated that $\mathrm{C}$ HSP11.0 contained a chaperonin cpn10 signature sequence (residues 8-32) but lacked an $\alpha$-crystallin domain. Multiple sequence alignments showed a $91.90 \%$ sequence identity between $\mathrm{C}$ CHSP11.0 and orthologous in other hymenopteran sHSPs (Figure 1A). The comparison of cDNA and genomic DNA of Cchsp11.0 cDNA indicated that the absence of introns (Figure 2A).

Full-length cDNA of Cchsf was 2073 bp (GenBank accession no. MT157267) and contained a 95-bp 5' UTR, an 1875-bp ORF, and a 103-bp 3' UTR (Figure S2). The deduced protein product contained 624 amino acids with a predicted mass of $70.03 \mathrm{kDa}$ and pI of 4.99. InterPro analysis indicated that $\mathrm{C} c \mathrm{HSF}$ contained four conversed domains including a DNA-binding domain (DBD), the hydrophobic heptad repeats HR-A/B and HR-C, and the C-terminal trans-activation domain (CTAD); these spanned residues 10-113, 131-209, 484-518, and 569-583, respectively. Multiple sequence alignments revealed that $\mathrm{CcHSF}$ shared $31.21 \%, 55.83 \%, 30.81 \%$ and $30.97 \%$ identity with HSFs in B. mori, Apis mellifera, $M$. brassicae, and H. armigera (Figure 1B). No introns were found in Cchsf when cDNA and genomic sequences were compared (Figure 2B).

\subsection{Phylogenetic Analysis of Genes}

Similar phylogenetic trees were obtained using neighbor-joining, maximum likelihood, maximum parsimony and minimum evolution methods. The dendogram in Figure 3 shows the results obtained with the neighbor-joining method due to its relatively accurate and fast calculation speed. Analysis using Clustal X and MEGA X [33] indicated that CcHSP11.0 was closely related to other hymenopteran insects (Figure 3A); furthermore, it should also be noted that these orthologous proteins contain the chaperonin cpn10 signature. The deduced protein sequence of $\mathrm{CcHSF}$ shared high similarity with other insects and select mammalian orthologues (Figure 3B) that also contained the four conserved HSF domains (data not shown).

\subsection{Gene Expression in Response to Different Temperatures}

The relative mRNA levels of Cchsp11.0 and Cchsf were monitored at temperature gradients ranging from $-13{ }^{\circ} \mathrm{C}$ to $36^{\circ} \mathrm{C}$ (Figure 4). Expression of Cchsp11.0 and Cchsf showed similar expression patterns at different temperatures. The expressions of these two genes were both up-regulated by cold stress while remained unchanged by heat stress (Cchsp11.0, $F_{9,20}=31.933, P<0.001 ;$ C Chsf: $\left.F_{9,19}=63.093, p<0.001\right)$. Compared to the control $\left(27^{\circ} \mathrm{C}\right)$, the relative expression of Cchsp11.0 and Cchsf were remarkably up-regulated at $-6^{\circ} \mathrm{C}$, and the expression was 12.33 -fold and 65.45 -fold higher than the control, respectively. 
A

Cotesiachilonis
Nasonia vitripennis
Dinoponera quadiceps
Ceratina calacarata
Bombus impatiens
Apis dorsata
Megachilerotındata
Cotesiachilonis
Nasonia vitipennis
Dinoponera quadiceps
Ceratina calacarata
Bombus impatiens
Apis dorsata
Megachilerotondata

B

Cotesiachilonis Bombyx mori

Apis mellifera

Melicoverpaarmiger

Cotesiachilonis

Bombyx mori

Apis mellifera

Helicoverpacrmiger

Cotesiachilonis

Bombyx mori

Apis mellifera

Mamestra brassicae

Helicoverpaarmigera

Cotesiachilonis

Bombyx mori

Mamestra brassica

Helicoverpaarmigera

Cotesiachilonis

Bombyx mori

Apis mellifera

Helicoverpaarmigerc

Cotesiachilonis

Bombyx mori

Apis mellifera

Mamestra brassicae
Helicoverpaarmiger

Cotesiachilonis

Bombyxmori

Apis mellifera

Mamestra brassicae
Helicoverpaarmiger

Cotesiachilonis

Bombyx mori

Apis mellifera

Helicoverpaarmiger

Cotesiachilonis

Bombyx mori

Apis mellifera

Mamestra brassicae
Helicoverpaarmigera

Cotesiachilonis

Cotesiachilomis
Bombyxmori

Apis mellifera

Mamestra brassicae

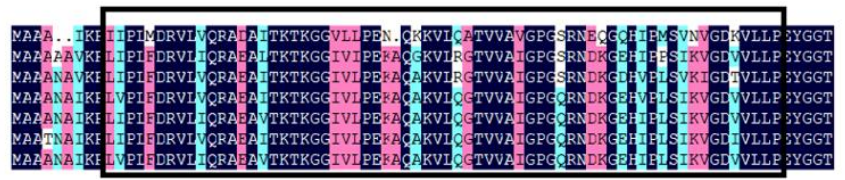

77
80
80
80
80
80
80
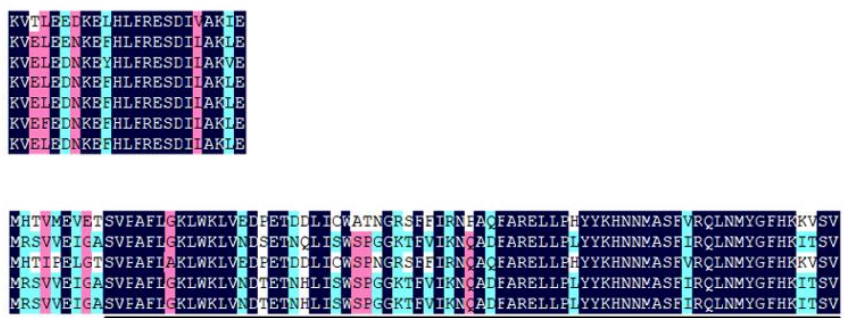

80
80
80
80
80

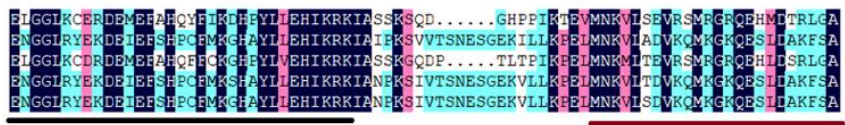

154
160
155
160
160

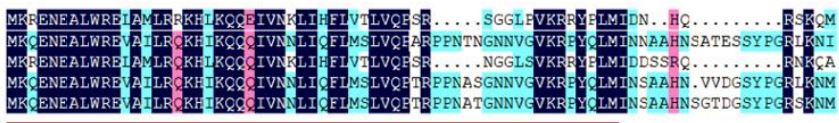

218
220
221
239
240

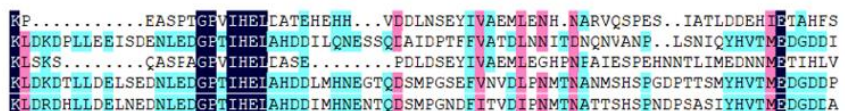

281
318
285
319
320

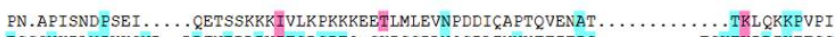
ESGGNKIAY PVKSNR ..LRENEDLPVITSP SPTQ.GKPSSPLNQSEAINNVFTITPS . . . . . . . . . . TSKTKPRIKTTSS DDSVCLQDDIQLINA ....EIEARKRRGCKGKRKEETHMLEMPLE...DSSVTALLE.............NRPVSKPVPM ETGANRLVY PVARNNGMNRTPESMPIITSASPTPIATSSMDQNGLDQVVNNYMGSPSPIVVKVEGHVPTKTKGRTNEANK

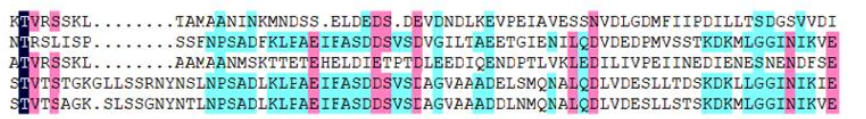

\section{457
419}

419
477

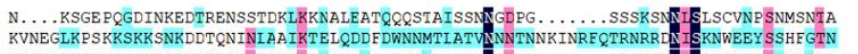

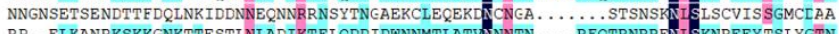

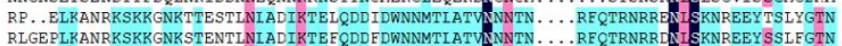

481
537
492
551

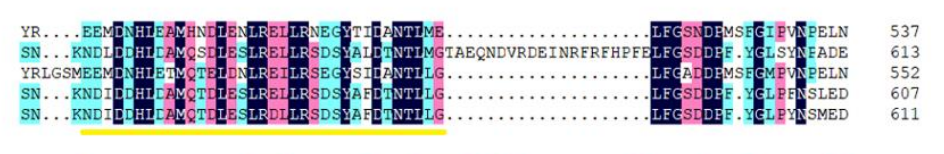

PTHHDKDQD $\ldots \ldots$ PVLANGATGGELMTYTP. SNLLDFDDDMLIATNNLLAESADGQNTINEFYNTDSMDLEDSKALIID RAKTSNNVAKKQK . . GDISNLCSDENRAEQ. FIEDDVEGNQLISYTGNIPDFEDINMPDLESENSQEGCLSPEVSSS P. HSEKEEDDHANVAENISGTSGGELNAYNPTSNLLDFDDDIELNATSP.VTSTAGDTATTSLYTSDPLDLEDNKVSI RTKTTNN. . AKKQR . . GEISNVSSDDSRVQHLFTEDNVEGNQLISYTGNIPDFEDINMPDLECDNSQEPCASPS PSSSTIN
RAKSANN. AKKQK . .GEISNVSSDDTRVQNLETEDNVEGNQLISYTGNI PDFEDINMPDLECDNSQEPCVLPS PSSSTLN

\section{SLVSGNGNSEANI.
TPQVQVRSPSINLK}

TPQVQVRSPSLNL

TPQMMVGSPSETIKK
TPQMQIRSESETLK

Figure 1. Amino acid sequence alignment of $C_{c} \mathrm{HSP} 11.0$ (A) and $C_{c} \mathrm{HSF}$ (B) from $C$. chilonis with orthologous proteins in B. mori, A. mellifera, M. brassicae, and H. armigera. Identical amino acids are shaded with the same color. The chaperonin cpn10 signature sequence is marked by a rectangle. The DNA-binding (DBD) motif, hydrophobic heptad repeats-heptad repeat ofhydrophobic amino acids A and B (HR-A/B) and C-terminal heptad repeat (HR-C) and C-terminal transactivation domain (CTAD) are underscored in black, red, yellow and green, respectively. Accession numbers of species are noted in Table S1. 
A
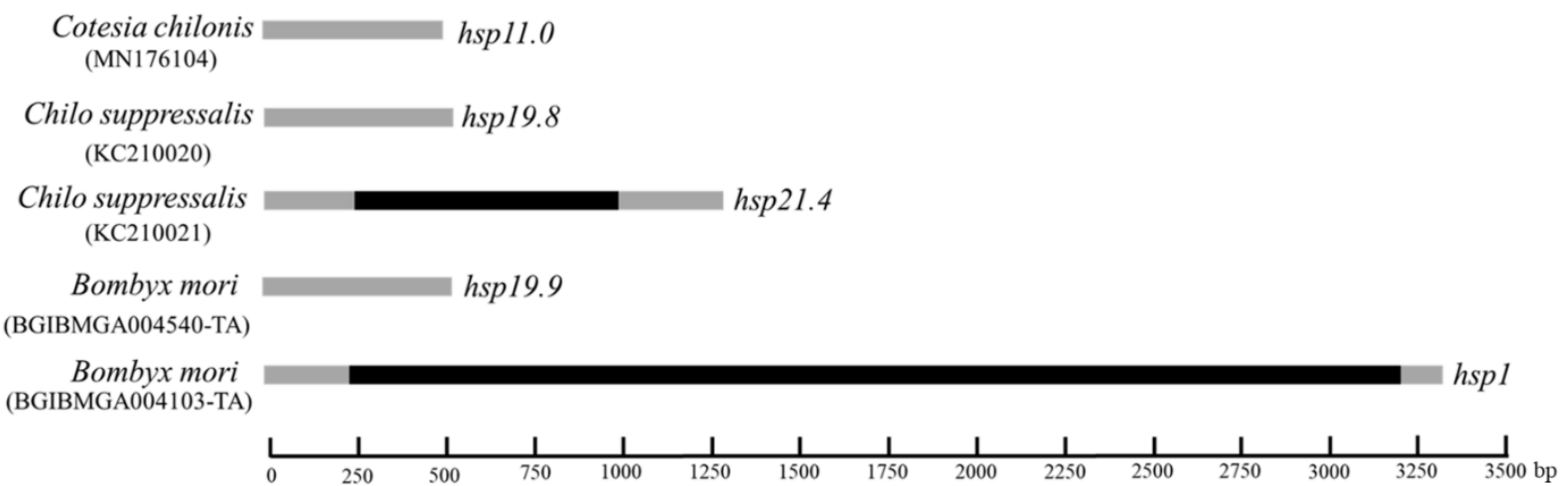

B

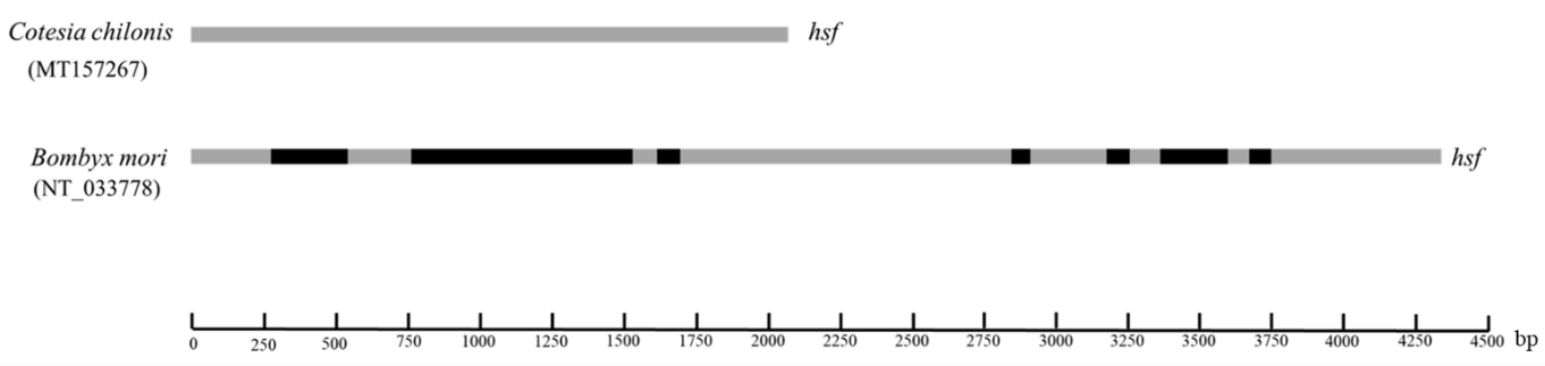

Figure 2. Diagrammatic representation of the genomic forms of shsp and hsf genes in C. chilonis, C. suppressalis and B. mori. (A) Gene structure of $h s p 11.0$ in C. chilonis, hsp19.8 and hsp.21.4 in C. suppressalis and hsp19.9 and hsp1 in B. mori. (B) Structure of $h s f$ genes in C. chilonis and B. mori. Gray and black rectangles are used to denote exons and introns, respectively.

\subsection{Time Course of Gene Expression After Temperature Treatments}

The relative mRNA levels of Cchsp11.0 and Cchsf were monitored using thermal treatments at different intervals ( $15 \mathrm{~min}$ to $8 \mathrm{~h}$ ); however, samples monitored at the $8 \mathrm{~h}$ time point were discarded due to high mortality. Gene expression patterns for Cchsp 11.0 and Cchsf were positively correlated for the different intervals after exposure to $36^{\circ} \mathrm{C}$ (Figure 5). The expression of Cchsp11.0 and Cchsf were both up-regulated at $15 \mathrm{~min}$ and $2 \mathrm{~h}$ after exposure to $36^{\circ} \mathrm{C}$ (Figure 5), and expression was 10.82- and 6.47-fold higher than the control at the 2-h time interval, respectively. At $-6^{\circ} \mathrm{C}$, both Cchsp 11.0 and Cchsf were significantly up-regulated at the 1 and $2 \mathrm{~h}$ intervals as compared to the control $\left(27^{\circ} \mathrm{C}\right)$; expression at the $4 \mathrm{~h}$ time period was negligible. The greatest expression of Cchsp11.0 and Cchsf was observed at $2 \mathrm{~h}$; at this time point, expression levels were 7.61- and 43.01-fold higher than control, respectively (Figure 6). 
A

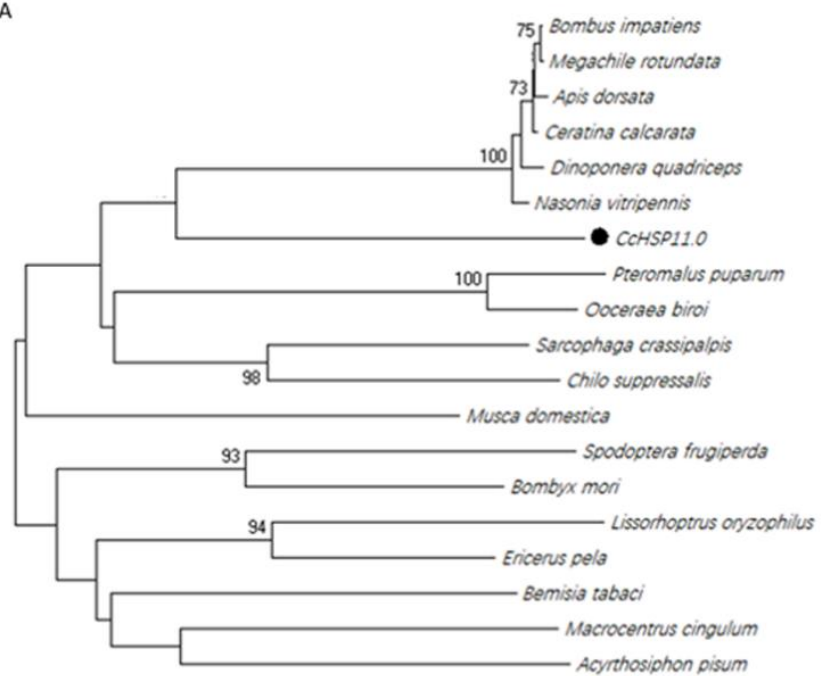

$\longmapsto 0.2$

B

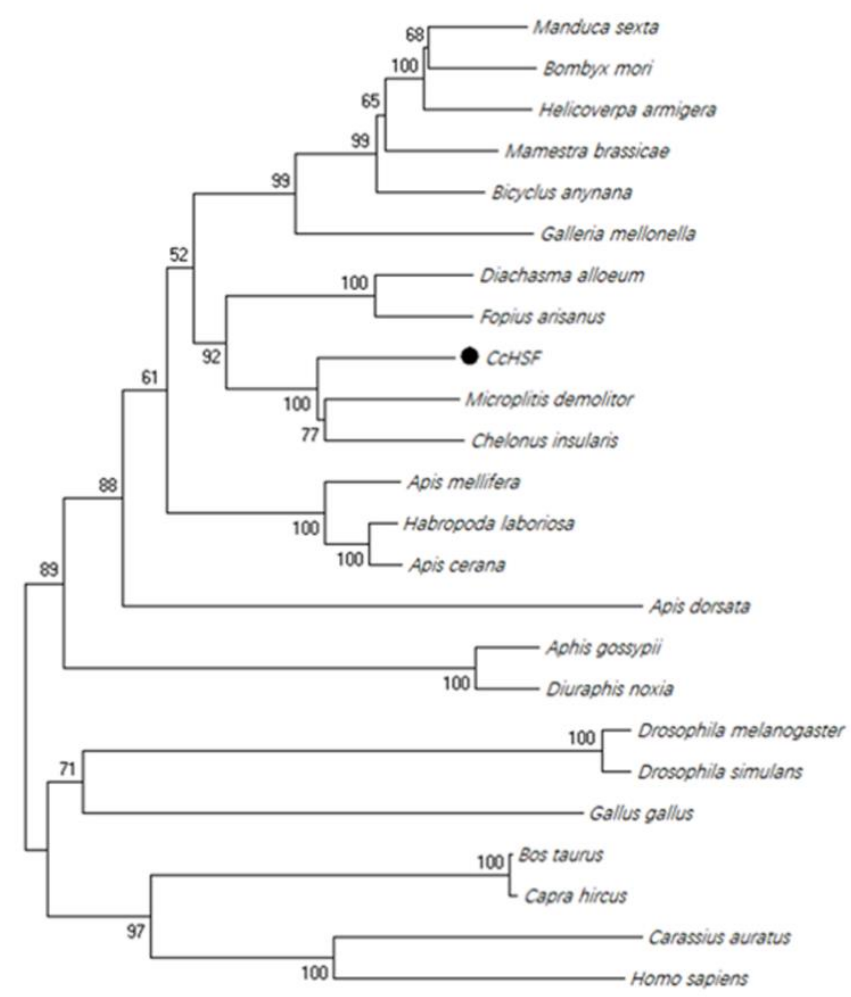

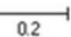

Figure 3. Phylogenetic analysis of HSP11.0 and heat shock transcription factor (HSF) proteins. (A) Relatedness of $\mathrm{CcHSP}$ in $\mathrm{C}$. chilonis to orthologues in other insects. (B) relatedness of $\mathrm{CcHSF}$ to proteins in other insects and mammals. Trees were generated with MEGA X, and solid circles indicate the location of CcHSP11.0 and CcHSF. Numbers on the branches are bootstrap values (1000 replicates), and only bootstrap $p$ values $>50$ are shown. Accession numbers are provided in Table S1. 


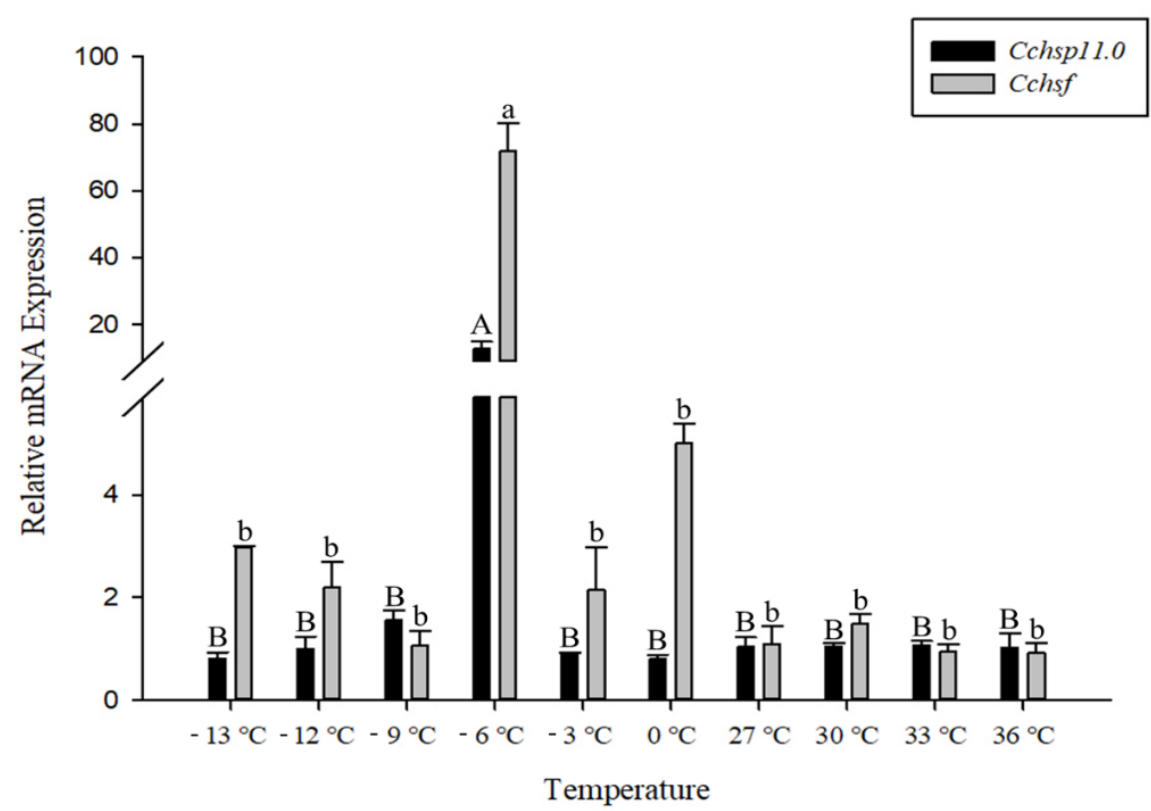

Figure 4. Relative mRNA expression levels of Cchsp11.0 and Cchsf at different temperatures. The control treatment is $27^{\circ} \mathrm{C}$. Statistics are presented as means $\pm \mathrm{SE}$ (standard error). Columns labeled with different letters indicate significance using one-way ANOVA followed by Tukey's multiple comparison analysis $(p<0.05)$. Uppercase letters indicate the significance of Cchsp11.0 and lowercase letters indicate the significance of Cchsf.

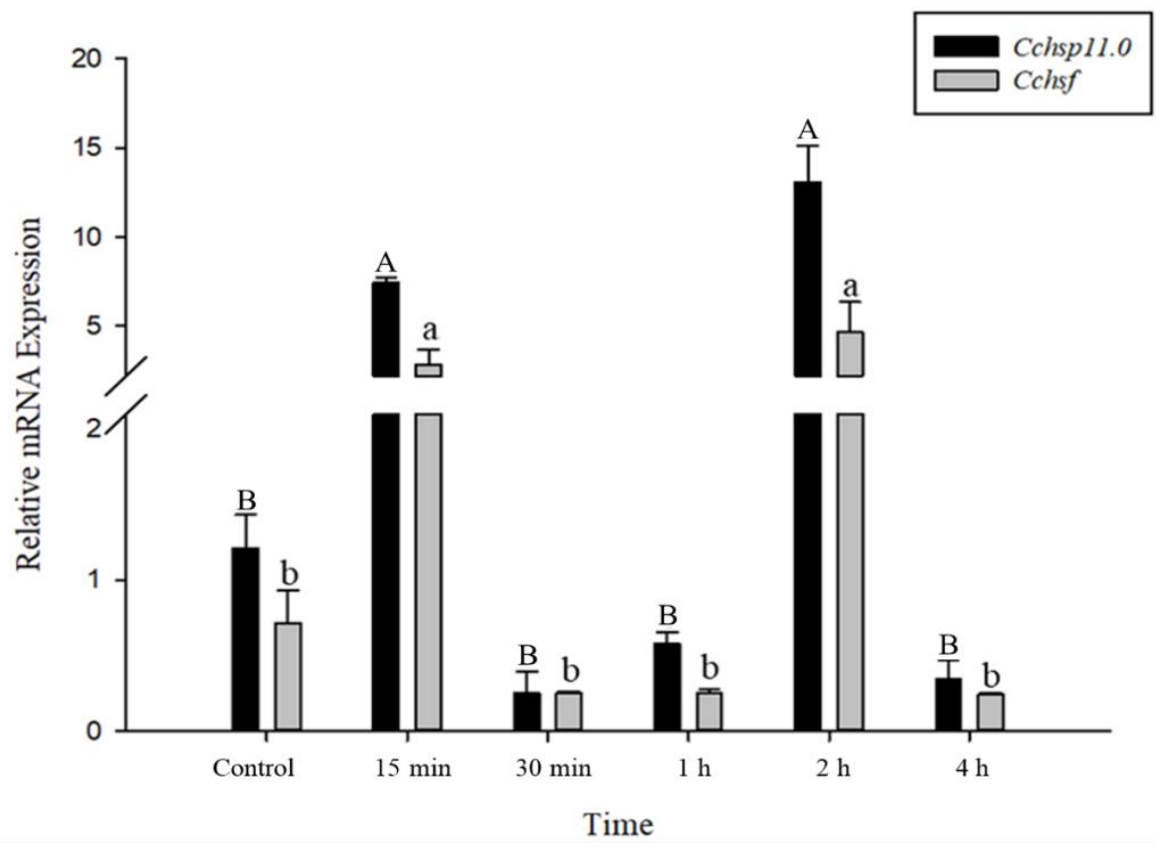

Figure 5. Relative mRNA expression levels of Cchsp11.0 and Cchsf at different intervals after exposure to $36^{\circ} \mathrm{C}$. Statistics represent means \pm SE. Columns labeled with different letters indicate significant differences between times using one-way ANOVA followed by Tukey's multiple comparison analysis $(p<0.05)$. Uppercase letters indicate the significance of Cchsp11.0 and lowercase letters indicate the significance of Cchsf. 


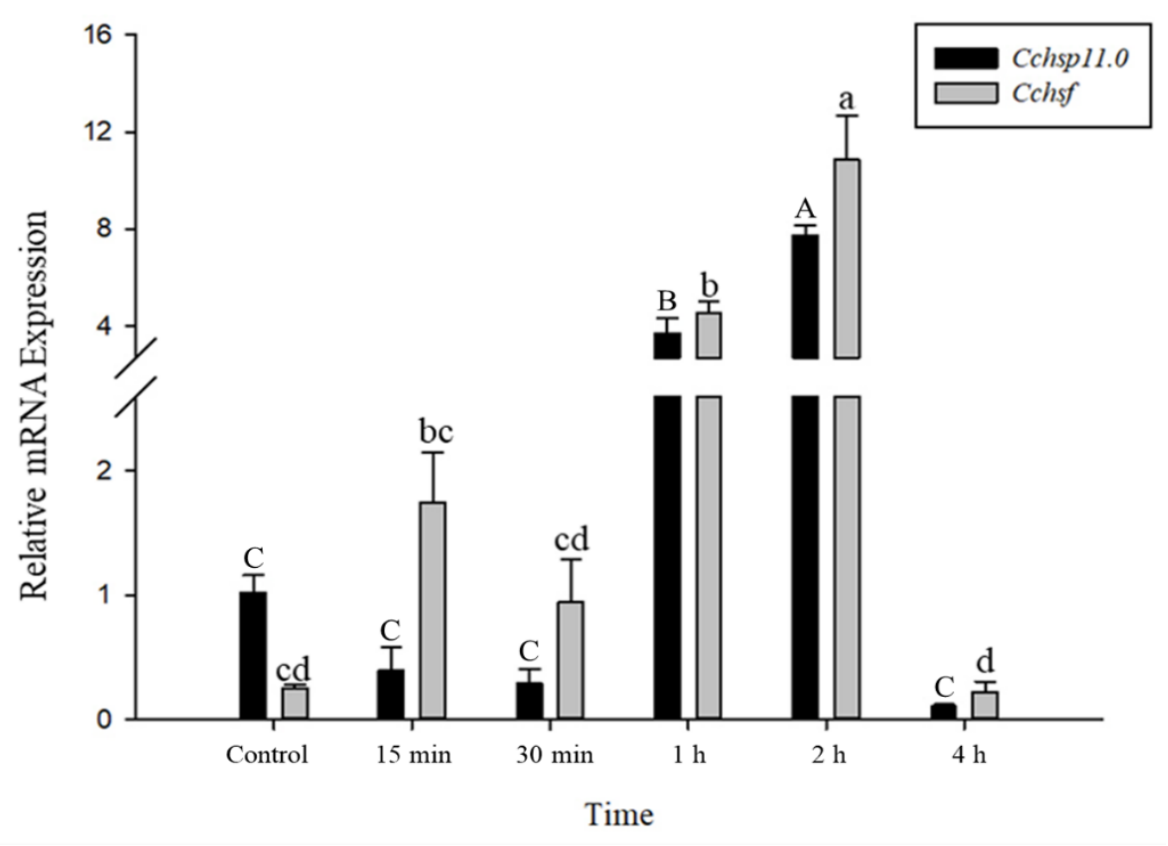

Figure 6. Relative mRNA expression levels of Cchsp11.0 and Cchsf at different intervals after exposure to $-6{ }^{\circ} \mathrm{C}$. Statistics are represented as means $\pm \mathrm{SE}$. Columns labeled with different letters indicate significant differences between times using one-way ANOVA followed by Tukey's multiple comparison analysis $(p<0.05)$. Uppercase letters indicate the significance of Cchsp11.0 and lowercase letters indicate the significance of Cchsf.

\section{Discussion}

HSPs and HSFs are key regulators and effectors of the heat shock response. In this study, we cloned and characterized the heat-induced Cchsp11.0 and the master regulator Cchsf in C. chilonis. Multiple sequence alignments and phylogenetic analysis showed that $\mathrm{CcHSP} 11.0$ and $\mathrm{CcHSF}$ are highly conserved and closely related to orthologues in other hymenopteran insects. $\mathrm{C} c \mathrm{HSF}$ contained four conversed domains widely found in heat shock factors. CcHSP11.0 contained a chaperonin cpn10 signature, which is not typical of sHSPs but belongs to a major of HSPs and controversially known as sHSP family [34,35]. The $10 \mathrm{kDa}$ heat shock protein, serving as molecular chaperone, co-chaperones with the HSP60 [36]. Further verification of gene sequences and genome structure revealed that there were no introns in either Cchsp11.0 or Cchsf, which may be part of the strategy used by C. chilonis to quickly activate transcription of these genes in response to temperature stress.

Temperature is a critical environmental factor that affects insect growth, development, distribution and abundance [37]. When subjected to high or low temperature stress, insects may adopt different coping strategies, such as avoidance behaviors or changing physiological functions to tolerate temperature stress [38]. Previous studies have shown that the tolerance of insects to temperature extremes is largely due to $h s p$ regulation and changes in $h s p$ expression [9,12]. In this study, Cchsp11.0 expression was significantly up-regulated at $-6{ }^{\circ} \mathrm{C}$; however, Cchsp11.0 did not respond to high temperature stress. In C. suppressalis, Cshsp21.5 was up-regulated by low but not high temperatures [23,39]; whereas, Cshsp21.4 and Cshsp21.7a were insensitive to temperature [38]. The expression levels of four shsps in Laodelphgax striatellus were up-regulated by high temperature [40], and Lthsp20.0 in L. trifolii was induced by both high and low temperatures [28]. These results indicate that insects have a complex network of small heat shock proteins with diverse expression patterns. The temperature tolerance of insects to extreme temperatures may be potentially improved by the interaction of different sHSPs; therefore, the expression patterns of shsps in C. chilonis warrant further study. 
Thermotolerance in organisms is generally accompanied by the induction of HSPs, which are regulated by heat shock transcription factors. In eukaryotic cells exposed to high temperatures, HSF1 was shown to activate its own transcription [16]. In this study, expression of Cchsf was not induced in response to high temperatures, but did show increased expression during cold stress. These results are consistent with findings reported by Guo (2013) who found that Bthsf in Bemisia tabaci can be induced by low but not high temperatures [41]. In contrast, $h s f$ in Marsupenaeus japonicus was induced in response to heat stress [42], which suggests that $h s f$ expression patterns vary in different insect species. In general, there are relatively few studies on the expression pattern of insect HSFs during temperature stress.

In time course experiments, the expression patterns of Cchsp11.0 and Cchsf transcription were positively correlated. Both Cchsp11.0 and Cchsf were induced at 15 min and $2 \mathrm{~h}$ after exposure to $36^{\circ} \mathrm{C}$. In addition to providing protection from heat stress, HSP10 functions as a chaperone to prevent the irreversible aggregation of proteins and as a cochaperonin with HSP60 [35]. Cchsp11.0 and Cchsf expression increased at the 15 min time point in response to heat stress and then declined until another round of induction $2 \mathrm{~h}$. The decreased expression of Cchsp11.0 at $30 \mathrm{~min}$ and $1 \mathrm{~h}$ may be related to the regulation of other HSPs [2], and the decline in Cchsf expression at these times may be related to the negative regulation of HSF by HSP. Previous studies showed that many small heat shock proteins have their maximum expression after $2 \mathrm{~h}$ of temperature treatment, such as Cshsp702, Cshsp19.8, Cshsp21.7b, Cshsp21.5, which is consistent with our experimental results $[1,23]$. At $4 \mathrm{~h}$, the expression of Cchsf decreased again, suggesting that HSF transcriptional activity is weakened somewhat over time [19,43]. Overall, Cchsf transcription was induced at lower levels than Cchsp11.0, perhaps because the regulation involves a conversion that affects its activity, such as its conversion from a monomer to a multimeric form or phosphorylation [41,44]. Additionally, the transcription of both Cchsp11.0 and Cchsf was induced at $-6{ }^{\circ} \mathrm{C}$ and was highest at $2 \mathrm{~h}$; however, expression of the two genes was minimal at $4 \mathrm{~h}$.

\section{Conclusions}

In conclusion, both Cchsp11.0 and Cchsf are sensitive to high and low temperature stress in C. chilonis, with maximal expression at $36{ }^{\circ} \mathrm{C}$ and $6{ }^{\circ} \mathrm{C}$ after $2 \mathrm{~h}$. The expression pattern of the two genes were strongly correlated at different times; however, the underlying mechanisms warrant further study in order to effectively control C. suppressalis using C. chilonis.

Supplementary Materials: The following are available online at https:/ / www.mdpi.com/article / 10.3390/insects12040322/s1, Figure S1: Nucleotide sequence and predicted protein sequence of Cchsp11.0 from Cotesia chilonis. The chaperonin cpn10 signature sequence is underscored. Figure S2: Nucleotide and predicted protein sequences of Cchsf from Cotesia chilonis. The DNA-binding (DBD), hydrophobic heptad repeats HR-A/B and HR-C and C-terminal trans-activation (CTAD) domains are underscored in black, red, yellow and green, respectively. Table S1: Accession numbers of species compared in this study.

Author Contributions: Data curation, F.-J.H., F.Z., M.-X.L., and Y.-Z.D.; funding acquisition, Y.-Z.D.; software, F.Z., and M.-X.L.; writing-original draft, F.-J.H. All authors have read and agreed to the published version of the manuscript.

Funding: This research was funded by the National Key R\&D Program of China (2017YFD0200400) and the National Basic Research Program of China (973 Program, 2013CB127604).

Institutional Review Board Statement: Not applicable.

Informed Consent Statement: Not applicable.

Data Availability Statement: Data are contained within the article or Supplementary Materials.

Acknowledgments: We sincerely thank Carol L. Bender for editing the manuscript prior to submission. 
Conflicts of Interest: The authors declare no conflict of interest.

\section{References}

1. Gao, P.; Lu, M.X.; Pan, D.D.; Du, Y.Z. Characterization of an inducible HSP70 gene in Chilo suppressalis and expression in response to environmental and biological stress. Cell Stress Chaperones 2019, 25, 65-72. [CrossRef] [PubMed]

2. Pan, D.D.; Cao, S.S.; Lu, M.X.; Hang, S.B.; Du, Y.Z. Genes encoding heat shock proteins in the endoparasitoid wasp, Cotesia chilonis, and their expression in response to temperatures. J. Integr. Agric. 2018, 17, 1012-1022. [CrossRef]

3. Chen, H.C.; Lou, Y.G.; Cheng, J.A. The research and application of Cotesia chilonis. Chin. J. Biol. Control 2002, 18, 90-93.

4. Pan, D.D.; Liu, Z.X.; Lu, M.X.; Cao, S.S.; Yan, W.F.; Du, Y.Z. Species and occurrence dynamics of parasitic wasps of the rice stem borer, Chilo suppressalis (Walker) (Lepidoptera: Pyralidae) in Yangzhou. J. Environ. Entomol. 2016, 38, 1106-1113.

5. Colinet, H.; Brent, J.; Sinclair, P.V.; David, R. Insects in fluctuating thermal environments. Annu. Rev. Entomol. 2015, 60, 123-140. [CrossRef]

6. Willmer, P.C.; Stone, G.; Johnston, I.A. Environmental physiology of animals. Blackwell 2000, 71, e1333.

7. Kerr, J.T.; Pindar, A.; Galpern, P.; Packer, L.; Potts, S.G.; Roberts, S.M.; Rasmont, P.; Schweigerm, O.; Colla, S.R.; Richardson, L.L.; et al. Climate change impacts on bumblebees converge across continents. Science 2015, 349, 177-180. [CrossRef]

8. Garcia, R.C.; Kuprewicz, E.K.; Staines, C.L.; Erwin, T.L. Limited tolerance by insects to high temperatures across tropical elevational gradients and the implications of global warming for extinction. Proc. Natl. Acad. Sci. USA 2016, 113, 680-685. [CrossRef]

9. Sinclair, B.J.; Alvarado, L.E.; Ferguson, L.V. An invitation to measure insect cold tolerance: Methods, approaches, and workflow. J. Therm. Biol. 2015, 53, 180-197. [CrossRef]

10. Martin-Folgar, R.; Aquilino, M.; Ozaez, I.; Martinez-Guitarte, J.L. Ultraviolet filters and heat shock proteins: Effects in Chironomus riparius by benzophenone-3 and 4-methylbenzylidene camphor. Environ. Sci. Pollut. R 2018, 25, 333-344. [CrossRef]

11. Tian, L.; Wang, X.Y.; Wang, X.P.; Lei, C.L.; Zhu, F. Starvation-, thermal- and heavy metal-associated expression of four small heat shock protein genes in Musca domestica. Gene 2018, 642, 268-276. [CrossRef]

12. Feder, M.E.; Hofmann, G.E. Heat-shock proteins, molecular chaperones, and the stress response: Evolutionary and ecological physiology. Annu. Rev. Physiol. 1999, 61, 243-282. [CrossRef]

13. Sørensen, J.G.; Kristensen, G.T.N.; Loeschcke, V. The evolutionary and ecological role of heat shock proteins. Ecol. Lett. 2003, 6, 1025-1037. [CrossRef]

14. Horwitz, J. Alpha-crystallin can function as a molecular chaperone. Proc. Natl. Acad. Sci. USA 1992, 89, 10449-10453. [CrossRef]

15. Akerfelt, M.; Morimoto, R.I.; Sistonen, L. Heat shock factors: Integrators of cell stress, development and lifespan. Nat. Rev. Mol. Cell Biol. 2010, 11, 545-555. [CrossRef] [PubMed]

16. Wiederrecht, G.; Seto, D.; Parker, C.S. Isolation of the gene encoding the S. cerevisiae heat shock transcription factor. Cell 1988, 6 , 841-853. [CrossRef]

17. Triandafillou, C.G.; Drummond, D.A. Heat shock factor 1: From fire chief to crowd-control specialist. Mol. Cell 2016, 63, 1-2. [CrossRef] [PubMed]

18. Kihara, F.; Niimi, T.; Yamashita, O.; Yaginuma, T. Heat shock factor binds to heat shock elements upstream of heat shock protein 70a and Samui genes to confer transcriptional activity in Bombyx mori diapause eggs exposed to $5^{\circ} \mathrm{C}$. Insect Biochem. Mol. 2011, 41, 843-851. [CrossRef] [PubMed]

19. Anckar, J.; Sistonen, L. Heat shock factor 1 as a coordinator of stress and developmental pathways. Adv. Exp. Med. Biol. 2017, $594,78-88$

20. Fujikake, N.; Nagai, Y.; Popiel, H.A.; Kano, H.; Yamaguchi, M.; Toda, T. Alternative splicing regulates the transcriptional activity of Drosophila heat shock transcription factor in response to heat/cold stress. FEBS Lett. 2005, 17, 3842-3848. [CrossRef] [PubMed]

21. Li, Z.W.; Li, X.; Yu, Q.Y.; Xiang, Z.H.; Kishino, H.; Zhang, Z. The small heat shock protein (sHSP) genes in the silkworm, Bombyx mori, and comparative analysis with other insect sHSP genes. BMC Evol. Biol. 2009, 9, 1-14. [CrossRef] [PubMed]

22. Shen, Y.; Gu, J.; Huang, L.H.; Zheng, S.C.; Liu, L.; Xu, W.H.; Feng, Q.L.; Kang, L. Cloning and expression analysis of six small heat shock protein genes in the common cutworm, Spodoptera litura. J. Insect Physiol. 2011, 57, 908-914. [CrossRef] [PubMed]

23. Lu, M.X.; Hua, J.; Cui, Y.D.; Du, Y.Z. Five small heat shock protein genes from Chilo suppressalis: Characteristics of gene, genomic organization, structural analysis, and transcription profiles. Cell Stress Chaperones 2014, 19, 91-104. [CrossRef] [PubMed]

24. Liu, Q.N.; Liu, Y.; Xin, Z.Z.; Zhu, X.Y.; Ge, B.M.; Li, C.F.; Wang, D.; Bian, X.G.; Yang, L.; Chen, L.; et al. A small heat shock protein 21 (sHSP21) mediates immune responses in Chinese oak silkworm Antheraea pernyi. Int. J. Biol. Macromol. 2018, 111, 1027-1031. [CrossRef]

25. Huang, L.H.; Wang, C.Z.; Kang, L. Cloning and expression of five heat shock protein genes in relation to cold hardening and development in the leaf miner, Liriomyza sativa. J. Insect Physiol. 2009, 55, 279-285. [CrossRef]

26. Sun, M.; Lu, M.X.; Tang, X.T.; Du, Y.Z. Characterization and expression of genes encoding three small heat shock proteins in Sesamia inferens (Lepidoptera: Noctuidae). Int. J. Mol. Sci. 2014, 15, 23196-23211. [CrossRef]

27. Song, J.; Cao, S.S.; Lu, M.X.; Du, Y.Z. Mortality and HSP genes expression in the endoparasitoid Cotesia chilonis (Hymenoptera: Braconidae) after cold acclimationat different temperatures. Ann. Entomol. Soc. Am. 2020, 113, 171-175. [CrossRef]

28. Chen, X.E.; Zhang, Y.L. Identification of multiple small heat-shock protein genes in Plutella xylostella (L.) and their expression profiles in response to abiotic stresses. Cell Stress Chaperones 2015, 20, 23-35. [CrossRef] 
29. Chen, W.; Geng, S.L.; Song, Z.; Li, Y.J.; Wang, H.; Cao, J.Y. Alternative splicing and expression analysis of HSF1 in diapause pupal brains in the cotton bollworm, Helicoverpa armigera. Pest. Manag. Sci. 2019, 75, 1258-1269. [CrossRef]

30. Sonoda, S.; Tsumuki, H. Characterization of alternatively spliced transcripts encoding heat shock transcription factor in cultured cells of the cabbage armyworm, Mamestra brassicae. Arch. Insect Biochem. 2010, 1, 49-60. [CrossRef]

31. Li, Q.Y.; Li, Z.L.; Lu, M.X.; Cao, S.S.; Du, Y.Z. Selection of valid reference genes for quantitative real-time PCR in Cotesia chilonis (Hymenoptera: Braconidae) exposed to different temperatures. PLoS ONE 2019, 14, e002679. [CrossRef] [PubMed]

32. Thompson, J.D.; Gibson, T.J.; Plewniak, F.; Jeanmougin, F.; Higgins, D.G. The Clustal-X windows interface: Flexible strategies for multiple sequence alignment aided by quality analysis tools. Nucleic Acids Res. 1997, 25, 4876-4882. [CrossRef] [PubMed]

33. Kumar, S.; Stecher, G.; Li, M.; Knyaz, C.; Tamura, K. MEGA X: Molecular evolutionary genetics analysis across computing platforms. Mol. Biol. Evol. 2018, 35, 1547-1549. [CrossRef] [PubMed]

34. Mishra, D.; Pareek, A.; Verma, J.K. The small heat shock proteins, chaperonin 10, in plants: An evolutionary view and emerging functional diversity. Environ. Exp. Bot. 2020, 4, 323.

35. Wang, H.J.; Shi, Z.K.; Shen, Q.D.; Xu, C.D.; Wang, B.; Meng, Z.J.; Wang, S.G.; Tang, B.; Wang, S. Molecular cloning and induced expression of six small heat shock proteins mediating cold-hardiness in Harmonia axyridis (Coleoptera: CoCcinellidae). Front. Physiol. 2017, 8, 60. [CrossRef]

36. Yang, J.; Gu, J.; Hu, Y.; Wang, N.; Wang, P. Molecular cloning and characterization of HSP60 gene in domestic pigeons (Columba livia) and differential expression patterns under temperature stress. Cell Stress Chaperones 2020, 4, 1-13. [CrossRef]

37. Bale, J.S.; Masters, G.J.; Hodkinson, I.D.; Awmak, C.; Bezemer, T.M.; Brown, V.; Butterfield, J.; Buse, A.; Coulson, J.C.; Farrar, J.; et al. Herbivory in global climate change research: Direct effects of rising temperature on insect herbivores. Glob. Chang. Biol. 2002, 8, 1-16. [CrossRef]

38. Hoffmann, A.A.; Sorensen, J.G.; Loeschcke, V. Adaptation of Drosophila to temperature extremes: Bringing together quantitative and molecular approaches. J. Therm. Biol. 2003, 28, 175-216. [CrossRef]

39. Song, J.; Lu, M.X.; Du, Y.Z. Molecular cloning and expression patterns of two small heat shock proteins from Chilo suppressalis (Walker). J. Integr. Agric. 2020, 19, 1522-1529. [CrossRef]

40. Wang, L.H.; Zhang, Y.L.; Pan, L.; Wang, Q.; Han, Y.C.; Niu, H.T.; Shan, D.; Hoffmann, A.; Fang, J.C. Induced expression of small heat shock protein is associated with thermotolerance in female Laodelphax striatellus planthoppers. Cell Stress Chaperones 2018, 24, 115-123. [CrossRef]

41. Guo, L.L. Heat shock regulatory factor Hsf's influence on Hsp60's expression in Invasion Whitefies. Henan Inst. Sci. Technol. 2013, 56, 145-167. (In Chinese)

42. Zheng, J.B.; Mao, Y.; Su, Y.Q.; Wang, J. Cross talk between heat shock protein 10 and a heat shock factor identified from Marsupenaeus japonicus. Int. J. Biol. Macromol. 2020, 147, 1041-1052. [CrossRef] [PubMed]

43. Nielsen, M.M.; Overgaard, J.; Sørensen, J.G.; Holmstrup, M.; Justesen, J.; Loeschcke, V. Role of HSF activation for resistance to heat, cold and high-temperature knock-down. J. Insect Physiol. 2005, 51, 1320-1329. [CrossRef] [PubMed]

44. Wu, C. Heat shock transcription factors: Structure and regulation. Annu. Rev. Cell Dev. Biol. 1995, 11, 441-469. [CrossRef] [PubMed] 